\title{
Endeavours to define optimal antithrombotic therapy after percutaneous coronary intervention
}

\author{
$\left(\begin{array}{l}2 \\ 2 \\ 2\end{array}\right.$ \\ Takeshi Kimura*, MD \\ Department of Cardiovascular Medicine, Kyoto University Graduate School of Medicine, Kyoto, Japan
}

Antithrombotic therapy is an adjunctive pharmacology integral to percutaneous coronary intervention (PCI) using coronary stents. In angiographic follow-up after implantation of self-expanding, stainless steel coronary stents (WALLSTENTTM; Boston Scientific, Marlborough, MA, USA) in 105 patients, Serruys et al reported complete stent occlusion in 25 patients $(24 \%)^{1}$. The antithrombotic regimen after stent implantation at that time included intravenous heparin followed by an oral vitamin $\mathrm{K}$ antagonist for three to six months together with aspirin and dipyridamole. This intensive antithrombotic regimen was also associated with high rates of bleeding complications. Therefore, thrombosis and bleeding were the serious limitations of coronary stenting. Subsequently, in a report by Colombo et al on 359 patients with Palmaz-Schatz coronary stent implantation, the addition of a $\mathrm{P}_{2} \mathrm{Y}_{12}$ receptor blocker, ticlopidine, together with high-pressure post-stent dilatation and intravascular ultrasound guidance resulted in extremely low rates of acute and subacute stent thrombosis $(0.6 \%$ and $0.3 \%$, respectively) without oral anticoagulation ${ }^{2}$. Stimulated by this seminal observation, the STARS (Stent Anticoagulation Restenosis Study) and ISAR (Intracoronary Stenting and Antithrombotic Regimen) trials were conducted. They demonstrated marked ( $\sim 80 \%$ ) reduction of the 30 -day incidence of ischaemic events, in particular stent thrombosis, by the addition of ticlopidine on top of aspirin $^{3,4}$. Based on these study results, dual antiplatelet therapy (DAPT) with aspirin and a $\mathrm{P} 2 \mathrm{Y}_{12}$ receptor blocker for one month has been firmly established as the standard of care after bare metal stent (BMS) implantation. Omission of anticoagulation resulted in a marked decrease of bleeding complications, thus opening up a new era of widespread use of coronary stents.

Subsequently, the introduction of the drug-eluting stent (DES) drastically reduced the incidence of restenosis due to profound inhibition of neointimal hyperplasia ${ }^{5,6}$. However, the delayed healing and inflammatory reactions after DES demonstrated in human autopsy studies raised concerns on the potentially higher risk for stent thrombosis after DES implantation with DAPT for one month ${ }^{7,8}$. These theoretical concerns urged the interventional cardiology community to prolong the duration of DAPT after DES implantation based not on scientific evidence, but rather on inferences. However, it has not yet been established how long we should continue DAPT after DES implantation in a mandatory fashion. Also, there remain issues on the optimal antithrombotic regimen after this "mandatory" DAPT period".

\section{Optimal duration for "mandatory" DAPT after DES implantation}

We might define the "mandatory" DAPT period after DES implantation as the period when DAPT is implemented to prevent stent thrombosis rather than to provide secondary prevention. Among the 10 randomised trials comparing DAPT durations, seven trials compared a DAPT duration of three to six months with that of one year or longer ${ }^{10-16}$. In a meta-analysis of 15,870 patients from these seven trials, shorter DAPT (three to six months) was 
associated with significantly lower risk for clinically significant bleeding (HR 0.57, 95\% CI: 0.40-0.81) without increasing the risk for stent thrombosis (HR 1.20, 95\% CI: 0.77-1.88) ${ }^{17}$. In the RESET (REal Safety and Efficacy of three-month dual antiplatelet Therapy following Endeavor zotarolimus-eluting stent implantation) and OPTIMIZE (Optimized Duration of Clopidogrel Therapy Following Treatment With the Zotarolimus-eluting Stent in Real-World Clinical Practice) trials, three months of DAPT was evaluated with the use of DES with relatively large late lumen loss, which means stent strut coverage similar to BMS; however, there has been no previous randomised controlled trial evaluating DAPT duration shorter than six months with the use of DES with small late lumen loss ${ }^{15,16}$. Therefore, based on the currently available data from randomised trials, the optimal duration for "mandatory" DAPT after DES implantation would be shorter than one year; six months of DAPT would be a reasonable choice at the present time. However, the absolute incidence of major bleeding is higher than that of stent thrombosis, and the mortality impact of bleeding might be greater than that of myocardial infarction ${ }^{18,19}$. Therefore, the endeavour to shorten further the duration of "mandatory" DAPT would be clinically relevant, if it could be safely accomplished without increasing the risk for stent thrombosis.

\section{Endeavours to achieve ultra-short DAPT}

In the STOPDAPT (ShorT and OPtimal duration of Dual AntiPlatelet Therapy after everolimus-eluting cobalt-chromium stent) prospective single-arm trial, we demonstrated the safety of three-month DAPT after cobalt-chromium everolimus-eluting stent (CoCr-EES) implantation. Compared with the historical CoCrEES group in the RESET (Randomized Evaluation of Sirolimuseluting versus Everolimus-eluting stent Trial), where nearly $90 \%$ of patients had continued DAPT at one year, the cumulative incidence of the primary endpoint (a composite of cardiovascular death, myocardial infarction, stroke, definite stent thrombosis and Thrombolysis In Myocardial Infarction [TIMI] major/minor bleeding at one year) trended to be lower in STOPDAPT than in RESET ( $2.8 \%$ versus $4.0 \%, \mathrm{p}=0.06)$, and the adjusted hazard ratio favoured STOPDAPT with three-month DAPT (HR 0.64, 95\% CI: 0.42-0.95, $\mathrm{p}=0.03$ ), with no definite stent thrombosis at one year among 1,525 study participants ${ }^{20,21}$. Thus, a "mandatory" DAPT duration of three months might be acceptable in selected patients with CoCr-EES implantation. Nevertheless, three-month DAPT would still be too long in patients with high bleeding risk.

In the LEADERS FREE (Prospective Randomized Comparison of the BioFreedom Biolimus A9 Drug-Coated Stent versus the Gazelle Bare-Metal Stent in Patients at High Bleeding Risk) trial, a polymer-free drug-coated stent was superior to BMS with respect to the primary safety endpoint of a composite of cardiac death, myocardial infarction, and stent thrombosis under a onemonth course of DAPT in patients at high bleeding risk ${ }^{22}$. With only a one-month course of DAPT, the rate of definite or probable stent thrombosis at one year with a polymer-free drug-coated stent was comparable to that with BMS (2.0\% and $2.2 \%$, respectively).
However, it might be important to note that the $2.0 \%$ rate of stent thrombosis at one year with a polymer-free drug-coated stent seemed to be higher than the rates reported for the new-generation polymer-based DES, in particular CoCr-EES ${ }^{23}$.

One step further from the LEADERS FREE trial results, the next logical research question would be "Is it equally safe to use polymer-based DES with small late lumen loss instead of a polymer-free drug-coated stent with only a one-month course of DAPT?". There has been no head-to-head large-scale comparison between a polymer-free drug-coated stent and a polymer-based DES. However, in ex vivo and in vivo experimental models, the thrombogenicity of polymer-coated CoCr-EES was lower than its bare metal counterpart. Contrary to popular perception, drug/polymer coatings do not inherently increase thrombogenicity, but actually reduce thrombosis $^{24}$. Furthermore, recent meta-analyses have clearly demonstrated a markedly lower risk of ST with CoCr-EES as compared with $\mathrm{BMS}^{25,26}$. We have been using BMS with only a one-month course of DAPT for more than 20 years without much concern on safety. One might argue why we adopt a DAPT duration longer than one month with the use of polymer-based DES, despite their less thrombogenic attribute as compared with BMS. In the case of BMS, there has been no randomised trial comparing the traditional one-month DAPT versus prolonged DAPT. In reality, the safety of one-month DAPT has not yet been formally established in patients who received BMS. However, in an observational study, we have demonstrated that a short DAPT duration of $<2$ months after BMS implantation was as safe as a prolonged DAPT duration of $>=2$ months, regardless of the clinical presentation with or without acute myocardial infarction ${ }^{27}$. Taking all these observations into account, it might be reasonable to hypothesise that $\mathrm{CoCr}$ EES and other new-generation polymer-based DES would achieve clinical outcomes at least comparable to, or even better than, polymer-free drug-coated stents under a one-month course of DAPT. Given this background, we have launched the STOPDAPT-2 (ShorT and OPtimal duration of Dual AntiPlatelet Therapy after everolimus-eluting cobalt-chromium stent-2; ClinicalTrials.gov number: NCT02619760) trial, which is a non-inferiority trial comparing onemonth DAPT with 12-month DAPT in terms of a primary composite endpoint of cardiovascular death, myocardial infarction, stroke, stent thrombosis, or TIMI major/minor bleeding in 3,000 patients who underwent PCI using CoCr-EES. In both arms, patients are on aspirin and a $\mathrm{P} 2 \mathrm{Y}_{12}$ receptor blocker (either clopidogrel or prasugrel) during the initial one-month period after stent implantation. Beyond one month, patients are on clopidogrel monotherapy in the experimental arm, while patients are on DAPT with aspirin and clopidogrel up to 12 months in the control arm. Two other large randomised trials are exploring one-month DAPT after polymer-based DES implantation. The Global LEADERS trial (ClinicalTrials.gov number: NCT01813435) is a superiority trial in terms of death or new Q-wave myocardial infarction, in which a new regimen involving DAPT with aspirin and ticagrelor for one month followed by ticagrelor monotherapy up to 24 months is compared with the standard regimen involving 12 months of DAPT followed 
by aspirin monotherapy up to 24 months in 16,000 patients who underwent PCI using a biodegradable polymer biolimus-eluting stent. Both Global LEADERS and STOPDAPT-2 are designed as all-comers trials. The MASTER-DAPT (MAnagement of patients post bioresorbable polymer STEnt implantation with an abbreviated DAPT regimen; ClinicalTrials.gov number: NCT03023020) trial will enrol 4,300 patients with high bleeding risk who underwent successful implantation of a biodegradable polymer sirolimuseluting stent. Following a mandatory one month of DAPT, patients will be randomised either to continue DAPT, or to transition to antiplatelet monotherapy to demonstrate non-inferiority at 12 months in terms of the primary endpoint of net adverse clinical events. Results from these ultra-short DAPT trials will provide crucial information to define the optimal duration of the "mandatory" DAPT period after DES implantation.

\section{Optimal antithrombotic regimen after the "mandatory" DAPT period}

Monotherapy with an antiplatelet agent would continue to be the bottom-line treatment after the "mandatory" DAPT period in patients with DES implantation. After stopping DAPT, lifelong administration of low-dose aspirin has been the standard of care in patients who underwent DES implantation. However, monotherapy with a $\mathrm{P} 2 \mathrm{Y}_{12}$ receptor blocker could also be an option, considering the concerns on gastrointestinal mucosal injury associated with low-dose aspirin monotherapy. CAPRIE (Clopidogrel versus Aspirin in Patients at Risk of Ischemic Events) is a 19,815-patient prospective randomised trial assessing the relative efficacy of clopidogrel $(75 \mathrm{mg}$ once daily) and aspirin (325 mg once daily) in reducing the risk of a composite endpoint of ischaemic stroke, myocardial infarction, or vascular death in patients with atherosclerotic vascular disease manifesting as either recent ischaemic stroke, recent myocardial infarction, or symptomatic peripheral arterial disease (PAD) ${ }^{28}$. Clopidogrel monotherapy as compared with aspirin monotherapy was associated with a significant $8.7 \%$ risk reduction for the primary endpoint (annual event rate: $5.32 \%$ vs. $5.83 \%$; HR 0.913 , 95\% CI: $0.835-0.97, \mathrm{p}=0.043$ ), and a numerically lower incidence of gastrointestinal bleeding $(1.99 \%$ vs. $2.66 \%)$, and intracranial bleeding $(0.35 \%$ vs. $0.49 \%)$. The relative risk reduction was greatest in the PAD subgroup (23.8\% [8.9-36.2], $\mathrm{p}=0.0028)$, followed by that in the stroke subgroup $(7.3 \%[-5.7-18.7], \mathrm{p}=0.26)$, and that in the myocardial infarction subgroup (-3.7\% [-22.1-12.0]). Driven by these subgroup analysis results in CAPRIE, and considering the cost-effectiveness issue, clopidogrel monotherapy was not regarded as the standard of care in the field of coronary artery disease. However, the CAPRIE trial was reported 20 years ago, in which very few patients with previous coronary stent implantation were included, and other medications were different from the current standard, in particular the use of statins. Also, the frequent need for the use of proton-pump inhibitors to prevent gastrointestinal mucosal injury and bleeding associated with aspirin use would diminish the favourable cost-effectiveness profile of aspirin as compared with a $\mathrm{P} 2 \mathrm{Y}_{12}$ receptor blocker. Therefore, it would be clinically relevant to revisit the relative efficacy of aspirin versus a $\mathrm{P} 2 \mathrm{Y}_{12}$ receptor blocker in a contemporary post-PCI population. In the STOPDAPT-2 trial, clopidogrel monotherapy will be continued up to five years after stopping DAPT at one month in the experimental arm, while aspirin monotherapy will be continued up to five years after stopping DAPT at 12 months in the control arm. In the Global LEADERS trial, ticagrelor monotherapy is continued up to two years after stopping DAPT at one month in the experimental arm, while aspirin monotherapy is continued up to two years after stopping DAPT at 12 months in the control arm. Longterm follow-up results from these trials would help define the optimal antithrombotic regimen after the "mandatory" DAPT period.

\section{More intensive antithrombotic therapy}

Another direction in the antithrombotic management in the chronic phase after DES implantation is the use of more intensive antithrombotic therapy for further prevention of ischaemic cardiovascular events. The Dual antiplatelet therapy (DAPT) study, a large international, multicentre, randomised, placebo-controlled trial, demonstrated that DAPT beyond one year up to 30 months after placement of a DES, as compared with aspirin therapy alone, significantly reduced the risks of stent thrombosis and major cardiovascular and cerebrovascular events ${ }^{29}$. Considering the current trend for the shorter period of "mandatory" DAPT after DES implantation, the DAPT study should be regarded as a secondary prevention trial. The DAPT study did not have any enriching criteria to focus on the high ischaemic risk patients, but enrolled only those patients who could tolerate DAPT for one year. Despite this elimination of high bleeding risk patients, prolonged DAPT as compared with aspirin alone was associated with significantly higher risk for GUSTO (Global Utilization of Streptokinase and Tissue Plasminogen Activator for Occluded Arteries) moderate/severe bleeding (2.5\% vs. 1.6\%, $\mathrm{p}=0.001)$. There was also a signal suggesting increased mortality in patients receiving prolonged DAPT $(2.0 \%$ vs. $1.5 \%, \mathrm{p}=0.05)$. In our recently published meta-analysis, we compared the efficacy and safety of prolonged DAPT in the DAPT study with that in the other nine trials comparing short versus long DAPT duration. Both the DAPT study and the other nine trials showed a significant reduction of stent thrombosis and myocardial infarction; however, the magnitude of risk reduction was much smaller in the nine trials than in the DAPT study (stent thrombosis: pooled OR $0.63[95 \%$ CI: $0.38-1.03$ ] versus OR 0.29 [95\% CI: $0.17-0.48]$ : $p=0.03$ for difference, and myocardial infarction: pooled OR 0.88 [95\% CI: $0.67-1.15$ ] versus OR 0.48 [95\% CI: $0.38-0.62$ ]: $\mathrm{p}=0.001$ for difference $^{30}$. On the other hand, prolonged DAPT as compared with aspirin alone across the 10 trials was associated with higher risk for bleeding (OR 1.79, 95\% CI: 1.45-2.22, $\mathrm{p}<0.001$ ), and for allcause death (OR 1.19, 95\% CI: 1.0-1.41, $\mathrm{p}=0.053$ ). The trends for excess risk of prolonged DAPT relative to aspirin alone for bleeding (OR 1.62 [95\% CI: 1.21-2.17] versus pooled OR 2.08 [95\% CI: 1.51-2.84]: $\mathrm{p}=0.25$ for difference), and for all-cause death (OR 1.31 [95\% CI: $0.97-1.78$ ] versus pooled OR 1.16 [95\% CI: 0.92-1.45]: 
$\mathrm{p}=0.53$ for difference) were seen consistently in both the DAPT and the other nine trials. The signal suggesting the excess mortality risk with prolonged DAPT seriously discourages the widespread use of prolonged DAPT in routine clinical practice.

Another trial exploring the use of more intensive antithrombotic therapy is the PEGASUS-TIMI 54 (Prevention of Cardiovascular Events in Patients with Prior Heart Attack Using Ticagrelor Compared to Placebo on a Background of Aspirin-Thrombolysis in Myocardial Infarction 54) trial, in which 21,162 patients who had had a myocardial infarction one to three years earlier were randomly assigned to ticagrelor at a dose of $90 \mathrm{mg}$ twice daily, ticagrelor at a dose of $60 \mathrm{mg}$ twice daily, or placebo on top of low-dose aspirin ${ }^{31}$. The patients had to have one of the following additional high-risk features: age 65 years or older, diabetes mellitus requiring medication, a second prior spontaneous myocardial infarction, multivessel coronary artery disease, or chronic renal dysfunction, defined as an estimated creatinine clearance of less than $60 \mathrm{ml}$ per minute. The two ticagrelor doses each reduced, as compared with placebo, the cumulative three-year incidence of the primary efficacy composite endpoint of cardiovascular death, myocardial infarction, or stroke (ticagrelor $90 \mathrm{mg}$ : 7.85\%, ticagrelor $60 \mathrm{mg}: 7.77 \%$, and placebo: $9.04 \%$; ticagrelor $90 \mathrm{mg}$ versus placebo: HR 0.85, 95\% CI: 0.75-0.96, p=0.008, and ticagrelor $60 \mathrm{mg}$ versus placebo: HR 0.84, 95\% CI: $0.74-0.95, p=0.004)$. Rates of TIMI major bleeding were higher with ticagrelor than with placebo $(2.60 \%, 2.30 \%$, and $1.06 \%, \mathrm{p}<0.001$ for each dose versus placebo). There was no signal suggesting increased mortality.

The most recently reported study exploring the use of more intensive antithrombotic therapy is the COMPASS (Cardiovascular Outcomes for People Using Anticoagulation Strategies) trial, in which 27,395 participants with stable atherosclerotic vascular disease were randomly assigned to receive rivaroxaban $(2.5 \mathrm{mg}$ twice daily) plus aspirin, rivaroxaban (5 $\mathrm{mg}$ twice daily), or aspirin $(100 \mathrm{mg} \text { once daily })^{32}$. Patients with coronary artery disease who were younger than 65 years of age were also required to have documentation of atherosclerosis involving at least two vascular beds or to have at least two additional risk factors (current smoking, diabetes mellitus, an estimated glomerular filtration rate $<60 \mathrm{ml}$ per minute, heart failure, or non-lacunar ischaemic stroke $\geq 1$ month earlier). The primary outcome (a composite of cardiovascular death, myocardial infarction, or stroke) was significantly reduced in the rivaroxaban-plus-aspirin group compared to the aspirin alone group ( $4.1 \%$ vs. $5.4 \%$; HR 0.76, 95\% CI: $0.66-0.86$, p $<0.001$ ), but the rate of major bleeding was significantly higher in the rivaroxaban-plusaspirin group compared to the aspirin alone group (3.1\% vs. $1.9 \%$; HR 1.70, 95\% CI: $1.40-2.05, \mathrm{p}<0.001)$. The rate of all-cause death was also significantly lower in the rivaroxaban-plus-aspirin group compared to the aspirin alone group ( $3.4 \%$ vs. $4.1 \%, \mathrm{p}=0.01)$.

Considering the results from these three trials, the use of a more intensive antithrombotic therapy could reduce ischaemic cardiovascular events, but consistently increase the bleeding events in patients with chronic stable coronary artery disease including postPCI patients. It would be important to note that the participants in these trials are carefully selected patients with high ischaemic risk, but without high bleeding risk. Balancing the risks and benefits is needed in considering more intensive antithrombotic therapy for patients with chronic stable coronary artery disease. Therefore, accurate risk stratification is mandatory in selecting the candidate patients for more intensive antithrombotic therapy. The DAPT study group has recently developed the DAPT score to estimate both the ischaemic and bleeding risks with a single scoring system $^{33}$. The DAPT score successfully identified the two groups of patients internally within the DAPT study in whom DAPT continuation beyond one year provided benefit of ischaemic protection and in whom it caused harm from bleeding. However, it still seems challenging to identify who derives benefit or harm from more intensive antithrombotic therapy, because the predictive factors for ischaemic and bleeding events often overlap. We should develop accurate and user-friendly risk scores that could stratify the ischaemic risk and the bleeding risk separately. In real clinical practice, the proportion of patients with high bleeding risk would be higher than that in randomised clinical trials. In patients with high bleeding risk, preventing bleeding events would be much more important than preventing ischaemic events. Thus, the use of more intensive antithrombotic therapy would be precluded in this patient population. Given the cost issue and the iatrogenic nature of the bleeding events under antithrombotic therapy, the benefits from more intensive antithrombotic therapy should far outweigh the risk. We should identify those patients with high ischaemic risk, but without high bleeding risk, in whom more intensive antithrombotic therapy would provide a substantial magnitude of absolute risk reduction for ischaemic events without increasing mortality.

\section{Conflict of interest statement}

The author has received research grants and honoraria from Abbott Vascular, Sanofi, AstraZeneca, and Bayer.

\section{References}

1. Serruys PW, Strauss BH, Beatt KJ, Bertrand ME, Puel J, Rickards AF, Meier B, Goy JJ, Vogt P, Kappenberger L, et al. Angiographic follow-up after placement of a self-expanding coronary-artery stent. $N$ Engl J Med. 1991;324:13-7.

2. Colombo A, Hall P, Nakamura S, Almagor Y, Maiello L, Martini G, Gaglione A, Goldberg SL, Tobis JM. Intracoronary stenting without anticoagulation accomplished with intravascular ultrasound guidance. Circulation. 1995;91:1676-88.

3. Leon MB, Baim DS, Popma JJ, Gordon PC, Cutlip DE, Ho KK, Giambartolomei A, Diver DJ, Lasorda DM, Williams DO, Pocock SJ, Kuntz RE. A clinical trial comparing three antithrombotic-drug regimens after coronary-artery stenting. Stent Anticoagulation Restenosis Study Investigators. N Engl J Med. 1998;339:1665-71.

4. Schömig A, Neumann FJ, Kastrati A, Schühlen H, Blasini R, Hadamitzky M, Walter H, Zitzmann-Roth EM, Richardt G, Alt E, Schmitt C, Ulm K. A randomized comparison of antiplatelet and anticoagulant therapy after the placement of coronary-artery stents. N Engl J Med. 1996;334:1084-9. 
5. Suzuki T, Kopia G, Hayashi S, Bailey LR, Llanos G, Wilensky R, Klugherz BD, Papandreou G, Narayan P, Leon MB, Yeung AC, Tio F, Tsao PS, Falotico R, Carter AJ. Stent-based delivery of sirolimus reduces neointimal formation in a porcine coronary model. Circulation. 2001;104:1188-93.

6. Morice MC, Serruys PW, Sousa JE, Fajadet J, Ban Hayashi E, Perin M, Colombo A, Schuler G, Barragan P, Guagliumi G, Molnar F, Falotico R; RAVEL Study Group. Randomized Study with the Sirolimus-Coated Bx Velocity Balloon-Expandable Stent in the Treatment of Patients with de Novo Native Coronary Artery Lesions. A randomized comparison of a sirolimus-eluting stent with a standard stent for coronary revascularization. $N$ Engl J Med. 2002;346:1773-80.

7. Joner M, Finn AV, Farb A, Mont EK, Kolodgie FD, Ladich E, Kutys R, Skorija K, Gold HK, Virmani R. Pathology of drug-eluting stents in humans: delayed healing and late thrombotic risk. J Am Coll Cardiol. 2006;48:193-202.

8. Virmani R, Guagliumi G, Farb A, Musumeci G, Grieco N, Motta T, Mihalcsik L, Tespili M, Valsecchi O, Kolodgie FD. Localized hypersensitivity and late coronary thrombosis secondary to a sirolimus-eluting stent: should we be cautious? Circulation. 2004;109:701-5.

9. Miyazaki Y, Suwannasom P, Sotomi Y, Abdelghani M, Tummala K, Katagiri Y, Asano T, Tenekecioglu E, Zeng Y, Cavalcante R, Collet C, Onuma Y, Serruys PW. Single or dual antiplatelet therapy after PCI. Nat Rev Cardiol. 2017;14:294-303.

10. Valgimigli M, Campo G, Monti M, Vranckx P, Percoco G, Tumscitz C, Castriota F, Colombo F, Tebaldi M, Fuca G, Kubbajeh M, Cangiano E, Minarelli M, Scalone A, Cavazza C, Frangione A, Borghesi M, Marchesini J, Parrinello G, Ferrari R; Prolonging Dual Antiplatelet Treatment After Grading StentInduced Intimal Hyperplasia Study (PRODIGY) Investigators. Short- versus long-term duration of dual-antiplatelet therapy after coronary stenting: a randomized multicenter trial. Circulation. 2012;125:2015-26.

11. Gwon HC, Hahn JY, Park KW, Song YB, Chae IH, Lim DS, Han KR, Choi JH, Choi SH, Kang HJ, Koo BK, Ahn T, Yoon JH, Jeong MH, Hong TJ, Chung WY, Choi YJ, Hur SH, Kwon HM, Jeon DW, Kim BO, Park SH, Lee NH, Jeon HK, Jang Y, Kim HS. Six-month versus 12-month dual antiplatelet therapy after implantation of drug-eluting stents: the Efficacy of Xience/Promus Versus Cypher to Reduce Late Loss After Stenting (EXCELLENT) randomized, multicenter study. Circulation. 2012;125:505-13.

12. Colombo A, Chieffo A, Frasheri A, Garbo R, MasottiCentol M, Salvatella N, Oteo Dominguez JF, Steffanon L, Tarantini G, Presbitero P, Menozzi A, Pucci E, Mauri J, Cesana BM, Giustino G, Sardella G. Second generation drug-eluting stent implantation followed by 6- versus 12-month dual antiplatelet therapy: the SECURITY randomized clinical trial. J Am Coll Cardiol. 2014;64:2086-97.

13. Gilard M, Barragan P, Noryani AAL, Noor HA, Majwal T, Hovasse T, Castellant P, Schneeberger M, Maillard L, Bressolette E, Wojcik J, Delarche N, Blanchard D, Jouve B, Ormezzano O,
Paganelli F, Levy G, Sainsous J, Carrie D, Furber A, Berland J, Darremont O, Le Breton H, Lyuycx-Bore A, Gommeaux A, Cassat C, Kermarrec A, Cazaux P, Druelles P, Dauphin R, Armengaud J, Dupouy P, Champagnac D, Ohlmann P, Endresen K, Benamer H, Kiss RG, Ungi I, Boschat J, Morice MC. 6- versus 24-month dual antiplatelet therapy after implantation of drug-eluting stents in patients nonresistant to aspirin: the randomized, multicenter ITALIC trial. J Am Coll Cardiol. 2015;65:777-86.

14. Schulz-Schüpke S, Byrne RA, Ten Berg JM, Neumann FJ, Han Y, Adriaenssens T, Tölg R, Seyfarth M, Maeng M, Zrenner B, Jacobshagen C, Mudra H, von Hodenberg E, Wöhrle J, Angiolillo DJ, von Merzljak B, Rifatov N, Kufner S, Morath T, Feuchtenberger A, Ibrahim T, Janssen PW, Valina C, Li Y, Desmet W, Abdel-Wahab M, Tiroch K, Hengstenberg C, Bernlochner I, Fischer M, Schunkert H, Laugwitz KL, Schömig A, Mehilli J, Kastrati A; Intracoronary Stenting and Antithrombotic Regimen: Safety And EFficacy of 6 Months Dual Antiplatelet Therapy After Drug-Eluting Stenting (ISAR-SAFE) Trial Investigators. ISAR-SAFE: a randomized, double-blind, placebo-controlled trial of 6 vs. 12 months of clopidogrel therapy after drug-eluting stenting. Eur Heart J. 2015;36:1252-63.

15. Kim BK, Hong MK, Shin DH, Nam CM, Kim JS, Ko YG, Choi D, Kang TS, Park BE, Kang WC, Lee SH, Yoon JH, Hong BK, Kwon HM, Jang Y; RESET Investigators. A new strategy for discontinuation of dual antiplatelet therapy: the RESET Trial (REal Safety and Efficacy of 3-month dual antiplatelet Therapy following Endeavor zotarolimus-eluting stent implantation). J Am Coll Cardiol. 2012;60:1340-8.

16. Feres F, Costa RA, Abizaid A, Leon MB, Marin-Neto JA, Botelho RV, King SB 3rd, Negoita M, Liu M, de Paula JE, Mangione JA, Meireles GX, Castello HJ Jr, Nicolela EL Jr, Perin MA, Devito FS, Labrunie A, Salvadori D Jr, Gusmao M, Staico R, Costa JR Jr, de Castro JP, Abizaid AS, Bhatt DL; OPTIMIZE Trial Investigators. Three vs twelve months of dual antiplatelet therapy after zotarolimus-eluting stents: the OPTIMIZE randomized trial. JAMA. 2013;310:2510-22.

17. Giustino G, Baber U, Sartori S, Mehran R, Mastoris I, Kini AS, Sharma SK, Pocock SJ, Dangas GD. Duration of dual antiplatelet therapy after drug-eluting stent implantation: a systematic review and meta-analysis of randomized controlled trials. J Am Coll Cardiol. 2015;65:1298-310.

18. Natsuaki M, Morimoto T, Furukawa Y, Nakagawa Y, Kadota K, Yamaji K, Ando K, Shizuta S, Shiomi H, Tada T, Tazaki J, Kato Y, Hayano M, Abe M, Tamura T, Shirotani M, Miki S, Matsuda M, Takahashi M, Ishii K, Tanaka M, Aoyama T, Doi O, Hattori R, Kato M, Suwa S, Takizawa A, Takatsu Y, Shinoda E, Eizawa H, Takeda T, Lee JD, Inoko M, Ogawa H, Hamasaki S, Horie M, Nohara R, Kambara H, Fujiwara H, Mitsudo K, Nobuyoshi M, Kita T, Kimura T; CREDO-Kyoto PCI/CABG registry cohort-2 investigators. Late adverse events after implantation of sirolimus-eluting stent and bare-metal stent: long-term (5-7 years) follow-up of the Coronary Revascularization Demonstrating Outcome study-Kyoto registry Cohort-2. Circ Cardiovasc Interv. 2014;7:168-79. 
19. Généreux P, Giustino G, Witzenbichler B, Weisz G, Stuckey TD, Rinaldi MJ, Neumann FJ, Metzger DC, Henry TD, Cox DA, Duffy PL, Mazzaferri E, Yadav M, Francese DP, Palmerini T, Kirtane AJ, Litherland C, Mehran R, Stone GW. Incidence, Predictors, and Impact of Post-Discharge Bleeding After Percutaneous Coronary Intervention. J Am Coll Cardiol. 2015;66:1036-45.

20. Natsuaki M, Morimoto T, Yamamoto E, Shiomi H, Furukawa Y, Abe M, Nakao K, Ishikawa T, Kawai K, Yunoki K, Shimizu S, Akao M, Miki S, Yamamoto M, Okada H, Hoshino K, Kadota K, Morino Y, Igarashi K, Tanabe K, Kozuma K, Kimura T. One-year outcome of a prospective trial stopping dual antiplatelet therapy at 3 months after everolimus-eluting cobalt-chromium stent implantation: ShorT and OPtimal duration of Dual AntiPlatelet Therapy after everolimus-eluting cobalt-chromium stent (STOPDAPT) trial. Cardiovasc Interv Ther. 2016;31:196-209.

21. Kimura T, Morimoto T, Natsuaki M, Shiomi H, Igarashi K, Kadota K, Tanabe K, Morino Y, Akasaka T, Takatsu Y, Nishikawa H, Yamamoto Y, Nakagawa Y, Hayashi Y, Iwabuchi M, Umeda H, Kawai K, Okada H, Kimura K, Simonton CA, Kozuma K; RESET Investigators. Comparison of everolimus-eluting and sirolimuseluting coronary stents: 1-year outcomes from the Randomized Evaluation of Sirolimus-eluting Versus Everolimus-eluting stent Trial (RESET). Circulation. 2012;126:1225-36.

22. Urban P, Meredith IT, Abizaid A, Pocock SJ, Carrie D, Naber C, Lipiecki J, Richardt G, Iñiguez A, Brunel P, ValdesChavarri M, Garot P, Talwar S, Berland J, Abdellaoui M, Eberli F, Oldroyd K, Zambahari R, Gregson J, Greene S, Stoll HP, Morice MC; LEADERS FREE Investigators. Polymer-free drugcoated coronary stents in patients at high bleeding risk. N Engl JMed. 2015;373:2038-47.

23. Toyota T, Morimoto T, Shiomi H, Yoshikawa Y, Yaku H, Yamashita Y, Kimura T. Very Late Scaffold Thrombosis of Bioresorbable Vascular Scaffold: Systematic Review and a MetaAnalysis. JACC Cardiovasc Interv. 2017;10:27-37.

24. Kolandaivelu K, Swaminathan R, Gibson WJ, Kolachalama VB, Nguyen-Ehrenreich KL, Giddings VL, Coleman L, Wong GK, Edelman ER. Stent thrombogenicity early in high-risk interventional settings is driven by stent design and deployment and protected by polymer-drug coatings. Circulation. 2011;123:1400-9.

25. Palmerini T, Benedetto U, Biondi-Zoccai G, Della Riva D, Bacchi-Reggiani L, Smits PC, Vlachojannis GJ, Jensen LO, Christiansen EH, Berencsi K, Valgimigli M, Orlandi C, Petrou M, Rapezzi C, Stone GW. Long-Term Safety of Drug-Eluting and Bare-Metal Stents: Evidence From a Comprehensive Network Meta-Analysis. J Am Coll Cardiol. 2015;65:2496-507.

26. Valgimigli M, Sabaté M, Kaiser C, Brugaletta S, de la Torre Hernandez JM, Galatius S, Cequier A, Eberli F, de Belder A, Serruys PW, Ferrante G. Effects of cobalt-chromium everolimus eluting stents or bare metal stent on fatal and non-fatal cardiovascular events: patient level meta-analysis. BMJ. 2014;349:g6427.
27. Natsuaki M, Morimoto T, Furukawa $Y$, Nakagawa $Y$, Kadota K, Ando K, Shiomi H, Toyota T, Watanabe H, Ono K, Shizuta S, Tamura T, Inoko M, Inada T, Shirotani M, Matsuda M, Aoyama T, Onodera T, Suwa S, Takeda T, Inoue K, Kimura T; CREDO-Kyoto PCI/CABG registry cohort-2 investigators. Short versus prolonged dual antiplatelet therapy duration after bare-metal stent implantation: 2-month landmark analysis from the CREDOKyoto registry cohort-2. Cardiovasc Interv Ther. 2016 Sep 19. [Epub ahead of print].

28. CAPRIE Steering Committee. A randomised, blinded, trial of clopidogrel versus aspirin in patients at risk of ischaemic events (CAPRIE). CAPRIE Steering Committee. Lancet. 1996;348: 1329-39.

29. Mauri L, Kereiakes DJ, Yeh RW, Driscoll-Shempp P, Cutlip DE, Steg PG, Normand SL, Braunwald E, Wiviott SD, Cohen DJ, Holmes DR Jr, Krucoff MW, Hermiller J, Dauerman HL, Simon DI, Kandzari DE, Garratt KN, Lee DP, Pow TK, Ver Lee P, Rinaldi MJ, Massaro JM; DAPT Study Investigators. Twelve or 30 months of dual antiplatelet therapy after drug-eluting stents. N Engl J Med. 2014;371:2155-66.

30. Toyota T, Shiomi H, Morimoto T, Natsuaki M, Kimura T. Short versus prolonged dual antiplatelet therapy (DAPT) duration after coronary stent implantation: A comparison between the DAPT study and 9 other trials evaluating DAPT duration. PLoS One. 2017; 12: 0174502 .

31. Bonaca MP, Bhatt DL, Cohen M, Steg PG, Storey RF, Jensen EC, Magnani G, Bansilal S, Fish MP, Im K, Bengtsson O, Oude Ophuis T, Budaj A, Theroux P, Ruda M, Hamm C, Goto S, Spinar J, Nicolau JC, Kiss RG, Murphy SA, Wiviott SD, Held P, Braunwald E, Sabatine MS; PEGASUS-TIMI 54 Steering Committee and Investigators. Long-term use of ticagrelor in patients with prior myocardial infarction. N Engl J Med. 2015;372:1791-800.

32. Eikelboom JW, Connolly SJ, Bosch J, Dagenais GR, Hart RG, Shestakovska O, Diaz R, Alings M, Lonn EM, Anand SS, Widimsky P, Hori M, Avezum A, Piegas LS, Branch KRH, Probstfield J, Bhatt DL, Zhu J, Liang Y, Maggioni AP, Lopez-Jaramillo P, O’Donnell M, Kakkar A, Fox KAA, Parkhomenko AN, Ertl G, Störk S, Keltai M, Ryden L, Pogosova N, Dans AL, Lanas F, Commerford PJ, TorpPedersen C, Guzik TJ, Verhamme PB, Vinereanu D, Kim JH, Tonkin AM, Lewis BS, Felix C, Yusoff K, Steg PG, Metsarinne KP, Cook Bruns N, Misselwitz F, Chen E, Leong D, Yusuf S; COMPASS Investigators. Rivaroxaban with or without Aspirin in Stable Cardiovascular Disease. N Engl J Med. 2017;377:1319-30.

33. Yeh RW, Secemsky EA, Kereiakes DJ, Normand SL, Gershlick AH, Cohen DJ, Spertus JA, Steg PG, Cutlip DE, Rinaldi MJ, Camenzind E, Wijns W, Apruzzese PK, Song Y, Massaro JM, Mauri L; DAPT Study Investigators. Development and Validation of a Prediction Rule for Benefit and Harm of Dual Antiplatelet Therapy Beyond 1 Year After Percutaneous Coronary Intervention. JAMA. 2016;315:1735-49. 